\title{
Performance of Lettuce (Lactuca sativa L.) Genotypes with Respect to Morphological, Yield and Quality Trials at Two Localities of Nepal.
}

\author{
Januka Dahal $^{1 *}$, Utshav Pandey ${ }^{2}$, Upakar Bhandari ${ }^{2}$, Sabina Tiwari ${ }^{2}$, Suchit Shrestha ${ }^{2}$ \\ ${ }^{\prime}$ Mahendra Ratna Multiple Campus, Ilam, Nepal \\ ${ }^{2}$ Karma Group of Companies, Kathmandu, Nepal. \\ "Corresponding Author's Email: janukadaha151@gmail.com. \\ "Orcid ID: https://orcid.org/0000-0001-5541-2406
}

Received on: 29 September 2020, Revised on: 3 April 2021, Accepted on: 12 April 2021

\begin{abstract}
Lettuce is cultivated as minor crop in Nepal. However, people are becoming more health conscious in these days and demand for salad is increasing in food. The demand of lettuce is also gradually increasing but relatively few farmers are involved in this crop due to the lack of high-yielding and good quality genotypes. The research was conducted at two locations of Nepal; Kavre and Kaski with the aim of evaluating the performance of seven different hybrid lettuce genotypes in terms of its morphology, yield, and quality. The research was laid out on Randomized Complete Block Design with three replications at each location. Two types of lettuce were used on the research i.e. head type and leaf type. Among the head type, genotype Iceberg performed better with more plant spread $(51 \mathrm{~cm})$, head diameter $(14.7 \mathrm{~cm})$ and yield $(738.4 \mathrm{~g}$ at Kavre and $725.8 \mathrm{~g}$ at Kaski) than other head type lettuce genotypes and among leaf type variety Green Oak was recorded with highest numbers of leaves (67 at Kavre and 40 at Kaski) and yield (572.3 g at Kavre and $641.9 \mathrm{~g}$ at Kaski). So, among head type lettuce genotypes Iceberg performed better as this had better plant spread, large head diameter, more yield and sweet flavor. Among leaf type genotypes Variety Green Oak was found most suitable for Nepali Market as this variety had highest number of leaves and yield among leaf type lettuce genotypes.
\end{abstract}

Keywords: Architecture, edible, head, interaction, parameters.

\section{Introduction:}

Lettuce (Lactuca sativa L.) is an important vegetable grown worldwide, it is the most consumed leafy vegetable and eaten as a salad. Lettuce is a member of family Asteraceae and is native to the Mediterranean area and Asia Minor, while it was domesticated in the shores of Egypt around 4500 B.C. (Swiader et al., 2002; Rubatzky \& Yamaguchi, 2012). However, the greatest species diversity can be found in the Mediterranean basin and Southwest Asia (Doležalová et al., 2001; Beharav et al., 2008; Kitner et al., 2008; Lebeda et al., $2009 \mathrm{a}, \mathrm{b})$.
It is mainly used in a caloric restricted diet; $100 \mathrm{~g}$ of lettuce doesn't have more than $25 \mathrm{kcal}$ (Sala \& Costa, 2012). Besides, it is a rich source of the mineral, fibers, and vitamins $\mathrm{A}, \mathrm{B} 1, \mathrm{~B} 2, \mathrm{~B} 5$, and $\mathrm{C}$ and can be used as medicine due to presence of different secondary metabolites (Ribeiro, 2016; Noumedem et al., 2017). Also, the nutritional components in lettuce are associated with the reduction in the risk of cardiovascular diseases and certain cancers (Hung et al., 2004; Chan, 2011). The main producers of lettuce in the world are the USA, Spain, Italy, Japan and, France (Bewley et al., 
2006). Lettuce is classified into four groups i.e. crisp head, butterhead, Romaine, and loose-leaf.

It is popular in tropical and sub-tropical countries but in temperate areas, it is grown under glass or plastic houses (Santos Filho et al., 2009; Fallovo et al., 2009). The total area under lettuce cultivation in Nepal is 78 hac while the total production is $773 \mathrm{mt}$ with average productivity $9.92 \mathrm{mt} / \mathrm{ha}$ and the major lettuce producing districts are Kavrepalanchowk, Kaski, Morang and Gorkha (MOAD, 2020). The demand for lettuce is also gradually increasing but relatively few farmers are involved in this crop farming due to the lack of high-yielding and good quality genotypes.
Therefore, the study was conducted at Karma Research and Development Stations of Kaski and Kavre districts to evaluate seven F1 high-yielding lettuce genotypes at two localities of Nepal.

\section{Materials and methods}

\section{Location}

This research was conducted at the two agro-ecological zones of Nepal i.e. Banepa, Kavre and Hemja, Kaski of Nepal from September 2019 to March 2020. The latitude, longitude, and elevation of sites are presented on table 1.

Table 1. Latitude, longitude and elevation of experimental sites.

\begin{tabular}{|c|c|c|c|}
\hline Location & Latitude & Longitude & Elevation \\
\hline Banepa, Kavre & $27^{\circ} 39^{\prime} 15.14^{\prime}$ N & $85^{\circ} 30^{\prime} 46.30^{\prime \prime} \mathrm{E}$ & 1461 masl. \\
\hline Hemja, Kaski & $28^{\circ} 16^{\prime} 2.00^{\prime \prime} \mathrm{N}$ & $83^{\circ} 57^{\prime} 0.00^{\prime \prime} \mathrm{E}$ & 1030 masl \\
\hline
\end{tabular}

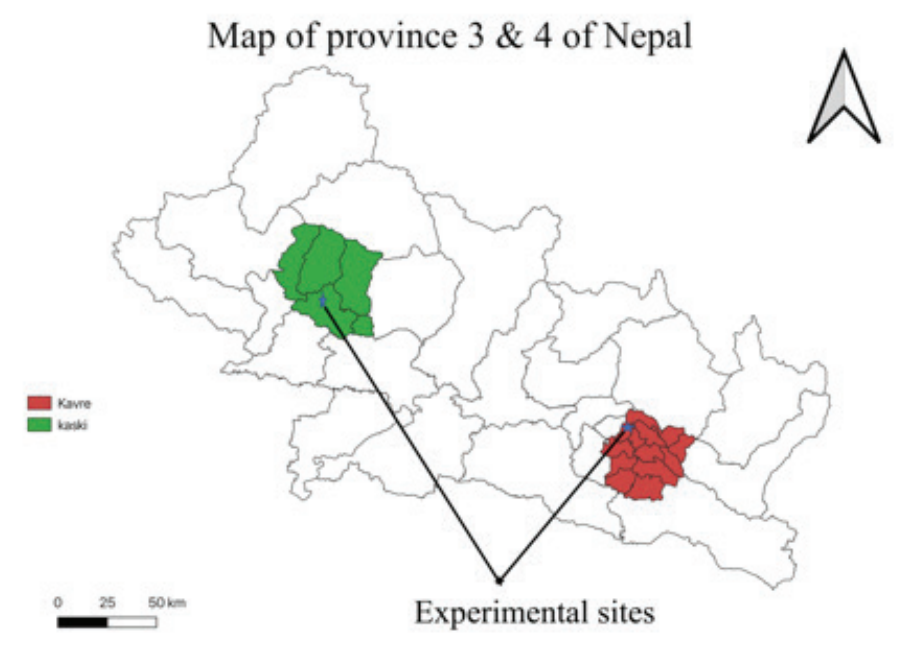

Figure 1. Administrative map showing the experimental locations.

\section{Climate and soil}

The average annual temperature at recorded at research site of Kaski is $19.7{ }^{\circ} \mathrm{C}$ and the rainfall is $2693 \mathrm{~mm}$ per year. Likewise, the average annual temperature and rainfall of recorded at site of Kavre district are $17.2^{\circ} \mathrm{C}$ and $1745 \mathrm{~mm}$ per year respectively.

The composite soil sample was taken from the top (0-30 $\mathrm{cm})$ layer of the experimental plot before transplanting lettuce seedlings. Instrumental analysis of soil was carried out to determine Soil $\mathrm{pH}$, Soil EC, and general visual and feeling method is used to determine the physical properties of soil. The information on soil analysis conducted at the Karma Groups of Companies is presented in table 2 . 
Table 2. Physical and chemical characteristics of soil of the two experimental sites, Nepal, 2019/2020.

\begin{tabular}{|l|c|c|c|}
\hline \multicolumn{1}{|c|}{ Location } & pH & EC & Texture \\
\hline Kavre & 6.1 & $0.49 \mathrm{mS} / \mathrm{cm}$ & Silty loam \\
\hline Kaski & 6.8 & $0.43 \mathrm{mS} / \mathrm{cm}$ & Sandy loam \\
\hline
\end{tabular}

\section{Experimental details}

The experiment was laid out on Randomized Complete Block Design (RCBD). This has seven F1 hybrid varieties of lettuce as treatments (Table 3) with three replications at each location. Twenty plants were adjusted on the plot of $2.4 \mathrm{~m}^{2}$. The crops were maintained at the geometry of $0.4 \mathrm{~m} \times 0.3 \mathrm{~m}$. The onemeter distance was maintained between two adjacent replications and $0.5 \mathrm{~m}$ space was left between two adjacent plots. Randomization of treatments was done by the lottery method.

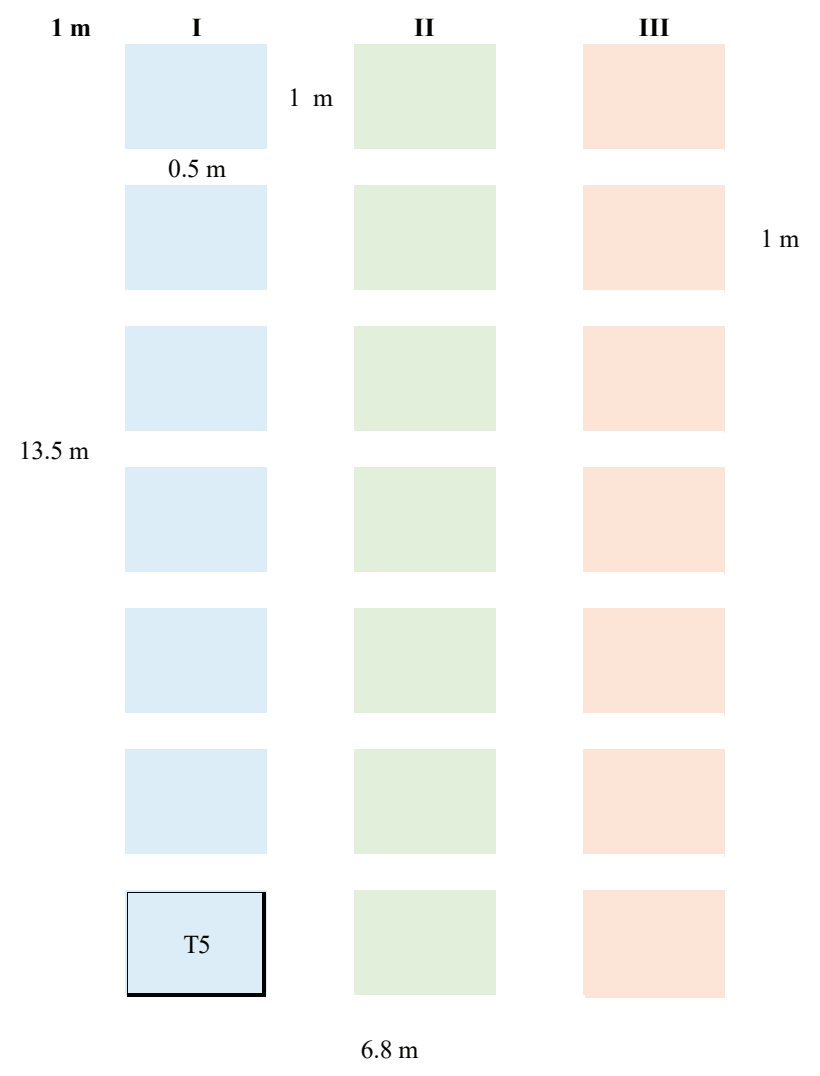

Figure 2. Layout and geometry of experimental field.

\section{Management practice}

The experimental field was prepared by deep digging, a week before the date of transplanting. The layout was done prior to transplanting. Akanee@ $58.3 \mathrm{gm}^{-2}$, Karma Bio@20.8 g m², Urea@16.7 g m², DAP@
$25 \mathrm{~g} \mathrm{~m}^{-2}$, MOP@20.8 $\mathrm{g} \mathrm{m}^{-2}$ and Herculus Utah one @ $4.2 \mathrm{~g} \mathrm{~m}^{-2}$ was applied as basal dose of fertilizer during the final landpreparation. Urea@1.9 g/plant is used for top dressing after 30 days of transplantation. Weekly spray schedule was followed as per package of practice of Karma Groups which included spray of NPK, micronutrients, fungicides, and insecticides. Seeds were sown on the tray with 128 holes on 12-Nov-2019. Seedlings at two true leaf stages were transplanted in on 12-Dec-2019. Dead plants were replaced within a week after transplanting. All the intercultural operations like weeding and hoeing were carried out when necessary. Irrigation was provided on a weekly basis through a water pipe.

\section{Observation}

Five randomly selected plants were observed for nine characters i.e., plant height $(\mathrm{cm})$, plant spread $(\mathrm{cm})$, number of leaves, leaf length $(\mathrm{cm})$, leaf breadth $(\mathrm{cm})$, head diameter $(\mathrm{cm})$, yield (g/plant)

\section{Data analysis}

All observed, measured and calculated data were encoded in Microsoft excel (MAC version 16.16.15) for data curation and management. R-program (version 3.5.2) was used for data analysis. Statistical tools such as two-way ANOVA was used to check significant differences between treatments and Least Significance Difference (LSD) at 0.05 significant level $\left(_{0.05}\right)$ was used to compare differences between treatment means.

\section{Results}

The result showed the interaction effect of genotypes and localities on all parameters except head diameter. Head diameter was significantly different only due to the genotypes. The details of the ANOVA test are shown in table 4 . below. 
Table 4. Analysis of variance showing effect of genotypes, locations and interaction between location and genotypes on various morphological and yield parameters.

\begin{tabular}{|l|c|c|c|}
\hline \multicolumn{1}{|c|}{ Parameters } & Location & Variety & Loc*Var \\
\hline Plant height & 0.1709 & $<2 \mathrm{e}-16 * * *$ & $0.0185 *$ \\
\hline Plant spread & $0.00618 * *$ & $<2 \mathrm{e}-16 * * *$ & $1.86 \mathrm{e}-05 * * *$ \\
\hline Number of leaves & $1.5 \mathrm{e}-15 * * *$ & $<2 \mathrm{e}-16 * * *$ & $<2 \mathrm{e}-16 * * *$ \\
\hline Leaf Length $(\mathrm{cm})$ & $2.32 \mathrm{e}-07 * * *$ & $<2 \mathrm{e}-16 * * *$ & $9.28 \mathrm{e}-05 * * *$ \\
\hline Leaf breadth $(\mathrm{cm})$ & 0.0596. & $<2 \mathrm{e}-16 * * *$ & $1.35 \mathrm{e}-14 * * *$ \\
\hline Head diameter $(\mathrm{cm})$ & 0.471 & $<2 \mathrm{e}-16^{* * *}$ & 0.982 \\
\hline Yield (g/plant) & $6.52 \mathrm{e}-08 * * *$ & $<2 \mathrm{e}-16 * * *$ & $3.04 \mathrm{e}-10 * * *$ \\
\hline
\end{tabular}

\section{Morphological parameter}

\section{Plant architecture}

Plant height varied significantly $(\mathrm{P} \leq 0.001)$ due to the genotypes and interaction of location and genotype was also observed. Plant spread was also significantly different according to the location $(\mathrm{P} \leq 0.01)$ and genotype $(\mathrm{P} \leq 0.001)$, in addition, a strong interaction of location and genotype was recorded. Maximum plant height was observed on the genotype Cos Lettuce (33 $\mathrm{cm}$ at Kavre and $34 \mathrm{~cm}$ at Kaski) and Red Coral Baby (34 cm at Kavre and $33 \mathrm{~cm}$ at Kaski) (Figure 3. (a)). Genotype Red Oak (19 cm) was observed with minimum plant height.

Likewise, according to figure 3. (b) maximum plant spread was recorded in the genotype Iceberg $(51 \mathrm{~cm})$, and the minimum spread was found on the genotype Mini Cos Lettuce (24 cm at Kavre and $22 \mathrm{~cm}$ at Kaski). However, the range of plant spread on most of the genotypes was 31 to $47 \mathrm{~cm}$. (a)

40

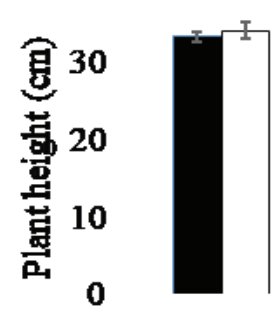

(b)

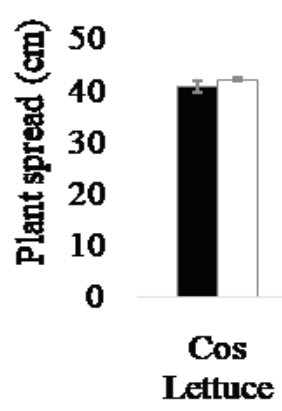

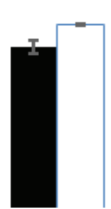
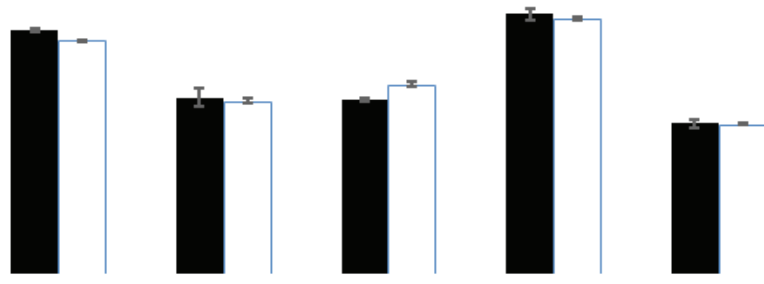

- Kavre $\square$ Kaski
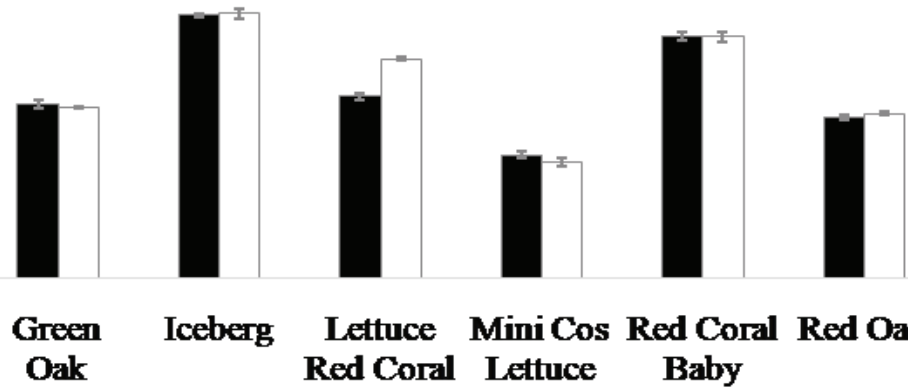

Red Coral Lettuce

Varieties

Figure 3. Interaction effect of genotypes and location on plant architecture of lettuce genotypes at Kavre and Kaski of Nepal during 2019/2020. Figure (a) plant height and (b) plant spread. 


\section{Number of leaves}

The number of leaves was significantly different $(\mathrm{P} \leq 0.001)$ according to the genotype and location. In addition, a strong interaction of location and genotype was also observed. Thenumbers of leaves were maximum at the location Kavre on all genotypes except on thegenotype Red Oak. Genotypes Cos Lettuce,
Iceberg, Mini Cos Lettuce was head type genotypes and on the remaining, leaves were the edible part. Green Oak (67.2 at Kavre and 40.1 at Kaski) was observed with maximum numbers of leaves and minimum numbers of leaves were observed on the genotype Mini Cos Lettuce (12.1 at Kavre and 9.1 at Kaski) (Figure 4.)

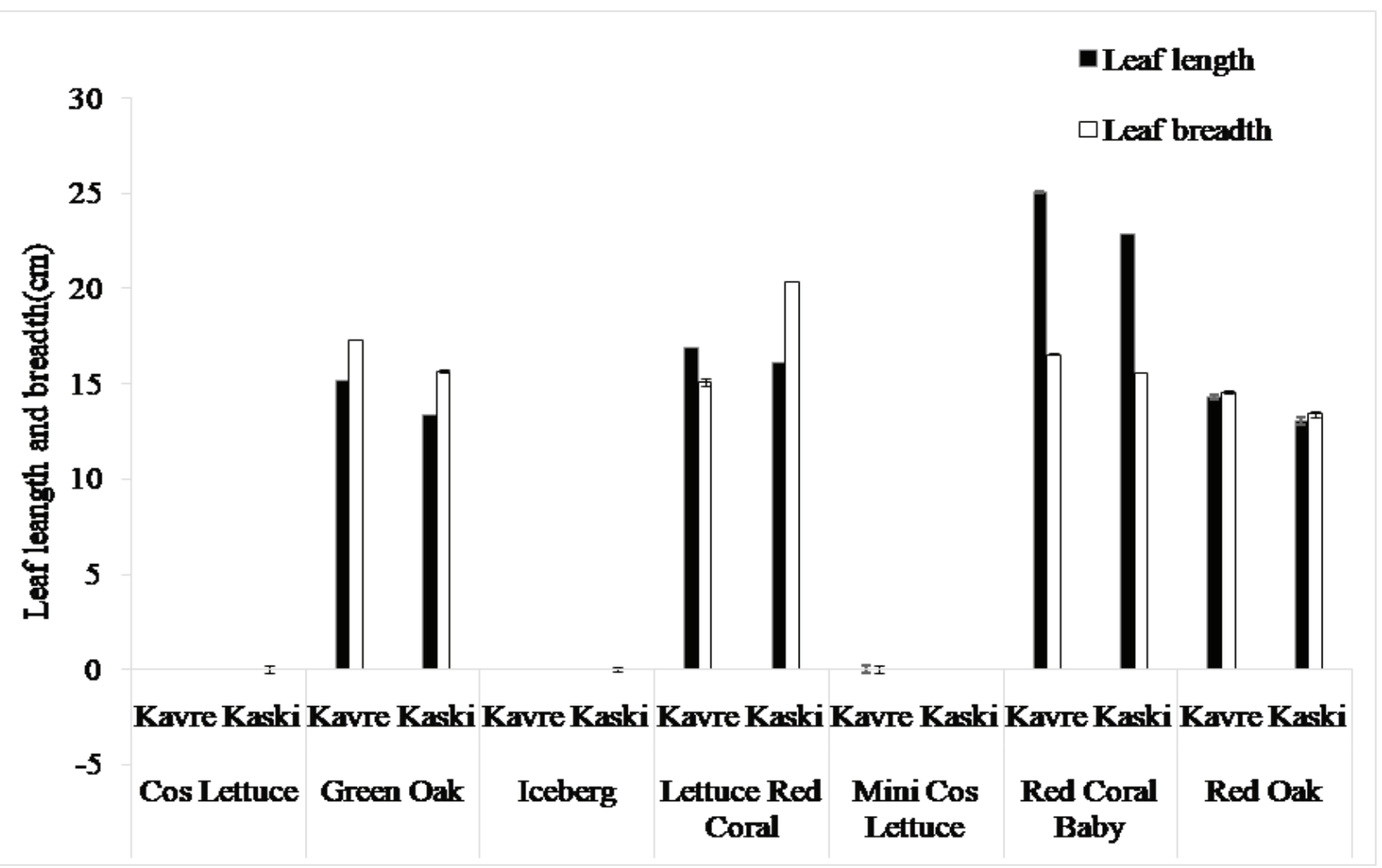

\section{Varieties}

Figure 4. Interaction effect of genotypes and location on number of leaves of lettuce genotypes at Kavre and Kaski of Nepal during 2019/2020.

\section{Leaf length and breadth (cm)}

Leaf length is influenced significantly $(\mathrm{P} \leq 0.001)$ due to the location and genotype also a significant effect of interaction between location and genotype was observed. While leaf breadth was significantly varied $(\mathrm{P} \leq 0.001)$ due to the genotype and interaction between location and genotype. According to figure 5. leaf length of the genotype Red Coral Baby was maximum (25 $\mathrm{cm}$ at Kavre and $23 \mathrm{~cm}$ at Kaski) and Red Oak genotype had the shortest leaf length (14 cm at Kavre and $13 \mathrm{~cm}$ at Kaski). In the same manner, the shortest leaf breadth was observed on the genotype Red Oak (15 $\mathrm{cm}$ at Kavre and $13 \mathrm{~cm}$ at Kaski) and maximum leaf breadth was observed on the genotype Lettuce Red Coral (15 cm at Kavre and $20 \mathrm{~cm}$ at Kaski).

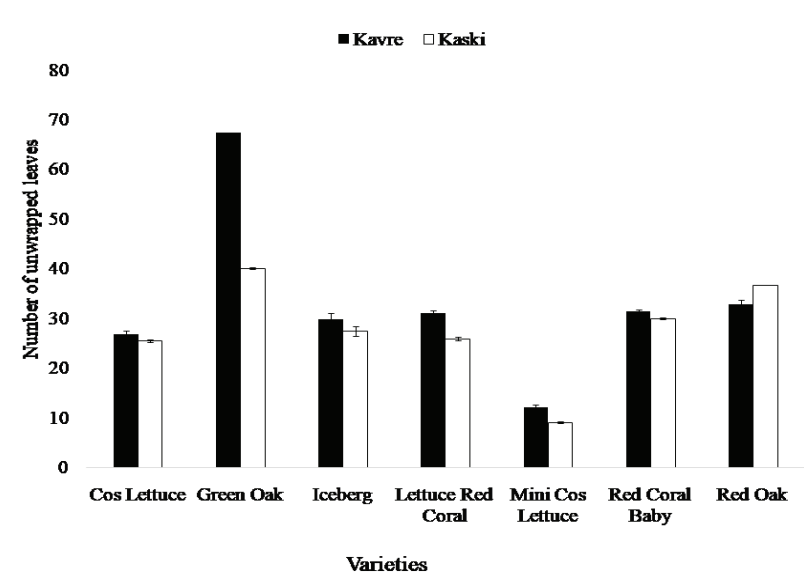

Figure 5. Interaction effect of genotypes and location on leaf length and breadth of lettuce genotypes at Kavre and Kaski of Nepal during 2019/2020. Figure (a) leaf length and (b) leaf breadth. 


\section{Equilateral head diameter (cm)}

The head diameter of lettuce genotypes varied significantly according to the genotypes $(\mathrm{P} \leq 0.001)$. Table 5. shows that the head diameter of the genotype Iceberg was highest $(14.7 \mathrm{~cm})$, followed by the genotype Mini Cos Lettuce $(6.1 \mathrm{~cm})$ and Cos Lettuce $(5.9 \mathrm{~cm})$. Theremaining four genotypes were leaf type genotypes.

Table 5. Mean values of head diameter of lettuce genotypes studied at Kavre and Kaski of Nepal during 2019/2020.

\begin{tabular}{|l|c|}
\hline \multicolumn{1}{|c|}{ Genotypes } & Equilateral head diameter (cm) \\
\hline Cos Lettuce & $5.9^{\mathrm{b}}$ \\
\hline Green Oak & $0.0^{\mathrm{c}}$ \\
\hline Iceberg & $14.7^{\mathrm{a}}$ \\
\hline Lettuce Red Coral & $0.0^{\mathrm{c}}$ \\
\hline Mini Cos Lettuce & $6.1^{\mathrm{b}}$ \\
\hline Red Coral Baby & $0.0^{\mathrm{c}}$ \\
\hline Red Oak & $0.0^{\mathrm{c}}$ \\
\hline Mean & $3.8^{* *}$ \\
\hline Pr $(>\mathrm{F})$ & $<2 \mathrm{e}-16^{* * *}$ \\
\hline LSD & 0.2 \\
\hline CV $(\%)$ & 5.0 \\
\hline
\end{tabular}

\section{Quality parameters}

Table 6. shows the quality parameters of lettuce genotypes. All genotypes were uniform in the field. Among the genotypes studied, three were of head type lettuce i.e Cos Lettuce, Iceberg, and Mini Cos Lettuce while remaining were of leaf type. Cos Lettuce had the oblong type of head, Iceberg had a round type of head while Mini Cos had somewhat block-shaped head. The visual analysis showed that Green Oak, Iceberg, Lettuce Red Coral and Red Oak had fan type of leaf shape, Cos lettuce and Red Coral Baby had oblong-shaped leaf

\section{Yield (g/plant)}

A significant impact $(\mathrm{P} \leq 0.001)$ of both genotypes and locations was observed on the parameter yield. Also, a strong interaction was recorded due to the location and genotypes. Figure 6 . shows that the maximum yield was observed on the genotype Iceberg (738.4 $\mathrm{g}$ at Kavre and $725.8 \mathrm{~g}$ at Kaski) and minimum yield was observed on the genotype Red Oak (291.8 g at Kavre and $353.9 \mathrm{~g}$ at Kaski). However, Lettuce Red Coral was observed with the yield $276.3 \mathrm{~g} / \mathrm{plant}$ at the location Kavre.

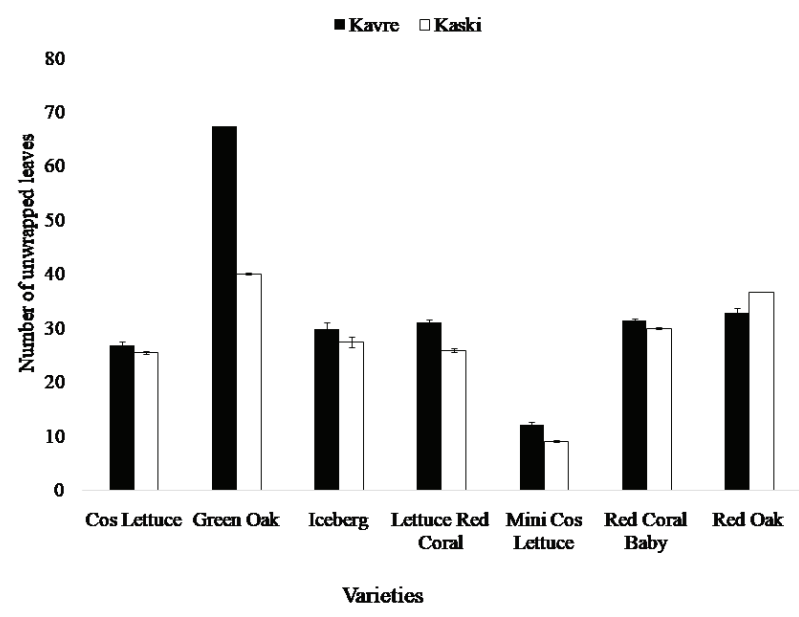

Figure 6. Interaction effect of genotypes and location on yield of lettuce genotypes at kavre and kaski of nepal during 2019/2020.

and Mini Cos had oval-shaped leaf. There were four types of leaf color i.e Light green, green, reddish, and reddish tinged green as shown in table 6. Sweet type of taste was found on the genotypes Cos Lettuce, Iceberg, Mini Cos Lettuce, and Red Coral Baby while typical lettuce flavor was observed on the genotypes Green Oak, Lettuce Red Coral, and Red Oak. Regarding the compactness, Cos Lettuce, Lettuce Red Coral and Red Coral Baby were slightly loose while remaining genotypes were compact.

Table 6. Morphological quality parameters of lettuce genotypes at Kavre and Kaski of nepal during 2019/2020.

\begin{tabular}{|c|c|c|c|c|c|c|c|}
\hline Genotypes & Uniformity & $\begin{array}{c}\text { Heading } \\
\mathbf{( \% )}\end{array}$ & $\begin{array}{c}\text { Head } \\
\text { shape }\end{array}$ & $\begin{array}{c}\text { Leaf } \\
\text { shape }\end{array}$ & $\begin{array}{c}\text { Leaf } \\
\text { color }\end{array}$ & Taste & Firmness \\
\hline Cos Lettuce & Uniform & 100 & Oblong & Oblong & Green & Sweet & $\begin{array}{c}\text { Slightly } \\
\text { loose }\end{array}$ \\
\hline Green Oak & Uniform & Leafy & - & Fan type & $\begin{array}{c}\text { Light } \\
\text { green }\end{array}$ & $\begin{array}{c}\text { Typical } \\
\text { lettuce flavor }\end{array}$ & Compact \\
\hline Iceberg & Uniform & 100 & Round & Fan type & Green & Sweet & Compact \\
\hline
\end{tabular}




\begin{tabular}{|c|c|c|c|c|c|c|c|}
\hline Genotypes & Uniformity & $\begin{array}{c}\text { Heading } \\
\mathbf{( \% )}\end{array}$ & $\begin{array}{c}\text { Head } \\
\text { shape }\end{array}$ & $\begin{array}{c}\text { Leaf } \\
\text { shape }\end{array}$ & $\begin{array}{c}\text { Leaf } \\
\text { color }\end{array}$ & Taste & Firmness \\
\hline $\begin{array}{c}\text { Lettuce Red } \\
\text { Coral }\end{array}$ & Uniform & Leafy & - & Fan type & Reddish & $\begin{array}{c}\text { Typical } \\
\text { lettuce flavor }\end{array}$ & $\begin{array}{c}\text { Slightly } \\
\text { loose }\end{array}$ \\
\hline $\begin{array}{c}\text { Mini Cos } \\
\text { Lettuce }\end{array}$ & Uniform & 100 & Block & Oval & Green & Sweet & Compact \\
\hline $\begin{array}{c}\text { Red Coral } \\
\text { Baby }\end{array}$ & Uniform & Leafy & - & Oblong & $\begin{array}{c}\text { Reddish } \\
\text { tinged } \\
\text { green }\end{array}$ & Sweet & $\begin{array}{c}\text { Slightly } \\
\text { loose }\end{array}$ \\
\hline Red Oak & Uniform & Leafy & - & Fan type & Reddish & $\begin{array}{c}\text { Typical } \\
\text { lettuce flavor }\end{array}$ & Compact \\
\hline
\end{tabular}

\section{Discussion}

Morphological parameters i.e. plant height and spread determines the plant architecture. The plant architecture can be utilized to determine the spacing required by plants. In leaf type of lettuce genotypes, loose leaves are edible parts and in head type heads are edible parts (Afton, 2018). Thus, the number of leaves, length and breadth of leaves, and head diameter tells about the amount of edible parts on lettuce genotypes. Interaction of locations and genotypes was also observed, this is due to the different responses of genotypes to different environmental conditions (Yan et al., 2007). The range of number of leaves reported by the finding of Sapkota et al. (2019) is 10-20 in hydroponic system which is different than our finding. The difference might be due to different growing condition, however, the variation in leaf length in theirs finding is similar to this result i.e. 9.75-25.06 cm. According to the experiment of Afton (2018) plant height ranged from $13.5-26.5 \mathrm{~cm}$ which is in line with this finding however, plant spread reported is quite different i.e. $26.7-32.5 \mathrm{~cm}$. Likewise, finding of Silva et al. (2019), Poliquit (2019), Afton (2018), and Tsiakaras et al. (2014) are in line with the finding of this research in terms of morphological variation.

Yield is directly related to the remuneration of farmers; more yield means more return to the farmers. Genotypes were different in terms of yield. Thakur et al. (2014) also reported yield range of 299.33-602.02 g. which is wide range like in this finding. The fresh weight of lettuce varieties in the experiment of Atikah, \& Widyawati (2019) was $20.39 \mathrm{~g}$ to $115.35 \mathrm{~g}$ and this is very different from the finding of this experiment This $20.30 \mathrm{~g}$ weight was observed on sandy soil while 115.35 $\mathrm{g}$ was observed on peat soil so, varieties may perform differently in different planting media. Wide range of variation in yield of lettuce genotypes have also been found by Silva et al. (2019), Lafta et al. (2017), Afton (2018), M'Hamdi et al. (2014) and Tsiakaras et al. (2014).

ConclusionThe study concludes that among head type lettuce genotypes Iceberg performed better as this had better plant spread, large head diameter, more yield, and sweet flavor. Among leaf type genotypes variety Green Oak was found most suitable for Nepali Market as this variety had the highest number of leaves and yield among leaf-type lettuce genotypes. Researches on more locations and genotypes can be conducted for further confirmation of the result as this was conducted only in two locations with seven genotypes. This research was conducted on open field condition, further experiments can be done inside polyhouse condition or in hydroponics system as lettuce leaves and heads need to be clean due to its consumption in raw form.

\section{Acknowledgment}

The authors are thankful to the Karma Group of Companies for fund and technical support in this research.

\section{Declaration of conflict of interest and ethical approval}

J.D was involved in designing and implementing the research and writing the manuscript. U.P, U.B and S.T did data collection and data entry work. S.S. participated in writing of the manuscript and provided guidelines for conducting the research. All the authors read manuscript carefully and declare that there are no conflicts of interest regarding the publication of this manuscript. The current article doesn't include any human participants and animals. 


\section{References}

Afton, W. D. (2018). Evaluation of Growth Characteristics, Yield, Marketability and Nitrate Levels of Lettuce (Lactuca sativa L.) Cultivars Produced in South Louisiana (Publication No. 4382) [Master's Thesis, Louisiana State University and Agricultural and Mechanical College]. Louisiana State University.

Atikah, T. A., \& Widyawati, W. (2019). The growth and yield of four varieties of lettuce (Lactuca sativa. L.) in different planting media. EurAsian Journal of BioSciences, 13(2), 2085-2091.

Beharav, A., Ben-DAvid, R., Doležalová, I., \& Lebeda, A. (2008). Eco-geographical distribution of Lactuca saligna natural populations in Israel. Israel Journal of Plant Sciences, 56(3), 195-206. DOI: 10.1560/IJPS.56.3.195

Bewley, J. D., Black, M., \& Halmer, P. (Ed). (2006). The encyclopedia of seeds: science, technology and uses. CABI. DOI: 10.1093/aob/mcm225

Chan, T. Y. (2011). Vegetable-borne nitrate and nitrite and the risk of methaemoglobinaemia Toxicology letters, 200(1-2), 107-108. DOI: $10.1016 /$ j.toxlet.2010.11.002

Doležalová, I., Lebeda, A., \& Křŕstková, E. (2001). Prickly lettuce (Lactuca serriola L.) germplasm collecting and distribution study in Slovenia and Sweden. Plant Genetic Resources Newsletter, 128, 41-44.

Fallovo, C., Rouphael, Y., Cardarelli, M., Rea, E., Battistelli, A., \& Colla, G. (2009). Yield and quality of leafy lettuce in response to nutrient solution composition and growing season. $J$. Food Agric. Environ, 7(2), 456-462.

Hung, H. C., Joshipura, K. J., Jiang, R., Hu, F. B., Hunter, D., Smith-Warner, S. A., Colditz, G.A., Rosner, B., Spiegelman, D., \& Willett, W. C. (2004). Fruit and vegetable intake and risk of major chronic disease. Journal of the National Cancer Institute, 96(21), 1577-1584. DOI: $\underline{10.1093 / \text { jnci/djh296 }}$

Kitner, M., Lebeda, A., Doležalová, I., Maras, M., Kř́stková, E., Nevo, E., Pavlíček, T., Meglic V., \&Beharav, A. (2008). AFLP analysis of Lactuca saligna germplasm collections from four European and three Middle Eastern countries. Israel Journal of Plant Sciences, 56(3), 185-193. DOI: $10.1560 /$ ijps.56.3.185
Lafta, A., Turini, T., Sandoya, G. V., \& Mou, B. (2017). Field evaluation of green and red leaf lettuce genotypes in the Imperial, San Joaquin, and Salinas Valleys of California for heat tolerance and extension of the growing seasons. HortScience, 52(1), 40-48. DOI: https:// doi.org/10.21273/HORTSCI10835-16

Lebeda, A., Doležalová, I., Křístková, E., Kitner, M., Petrželová, I., Mieslerová, B., \& Novotná, A. (2009a). Wild Lactuca germplasm for lettuce breeding: current status, gaps and challenges. Euphytica, 170(1-2), 15. DOI: 10.1007/s10681-009-9914-7

Lebeda,A., Kitner, M., Dziechciarková, M., Doležalová, I., Křístková, E., \&Lindhout, P. (2009b). An insight into the genetic polymorphism among European populations of Lactuca serriola assessed by AFLP. Biochemical Systematics and Ecology, 37(5), 597-608. DOI : 10.1016/j. bse.2009.10.010

MOAD, Nepal (2020). Statistical information on Nepalese agriculture 2018/19. Singha Durbar, Kathmandu,Nepal.

M'hamdi, M., Boughattas, I., Rouhou, H. C., Souhli, E., \& Bettaieb, T. (2014). Effect of different levels of nitrogen fertilizer on morphological and physiological parameters and nitrates accumulation of lettuce cultivars (Lactuca sativa L.). Research in Plant Biology, 4(4).

Noumedem, J.A.K., Djeussi, D.E., Hritcu, L., Mihasan, M, \& Kuete, V. (2017) Lactuca sativa. In Medicinal Spices and Vegetables from Africa, Academic Press: Cambridge, MA, USA, 2017, 437-449 P.

Poliquit, D. E. (2019). Growth and Yield of Lettuce (Lactuca sativa L.) as Influenced by the Residual Effects of Guano-Char. Asia Pacific Journal of Multidisciplinary Research, 7(2).

Rubatzky, V. E., \& Yamaguchi, M. (2012). World vegetables: principles, production, and nutritive values. Springer Science \& Business Media. DOI: $10.1007 / 978-1-4615-6015-9$

Sala, F. C., \& Costa, C. P. D. (2012). Retrospective and trends of Brazilian lettuce crop. Horticulturabrasileira, 30(2), 187194. DOI: https://doi.org/10.1590/S0102$\underline{05362012000200002 .}$. 
Santos Filho, B. G., Lobato, A. K. S., Silva, R. B., Schimidt, D., Costa, R. C. L., Alves, G. A. R., \&Neto, C. O. (2009). Growth of lettuce (Lactuca sativa L.) in protected cultivation and open field. Journal of Applied Sciences Research, 5(5), 529-533.

Sapkota, S., Sapkota, S., \& Liu, Z. (2019). Effects of nutrient composition and lettuce cultivar on crop production in hydroponic culture. Horticulturae, 5(4), 72. DOI: https:// doi.org/10.3390/horticulturae5040072

Silva, o., lopes, W. D. A. R., nunes, G. H. D. S., negreiros, M. Z. D., \&espínolasobrinho, J. O. S. É. (2019). Adaptability and phenotypic stability of lettuce cultivars in a semiarid region. Revista Caatinga, 32(2), 552-558. DOI: http://dx.doi. org/10.1590/1983-21252019v32n228rc

Swiader, J. M., Ware, G. W., \& McCollum, J. P. (2002). Sweet corn. Producing Vegetable Crops. Interstate Publishers, Inc., Danville, IL.
Thakur, M., Kumar, R., Kumar, S., Bhardwaj, M. L., \& Sharma, M. (2014). Genetic Divergence Studies in Lettuce (Lactuca sativa L) Under Protected Conditions in Mid Hills of Himachal Pradesh. International Journal of Agriculture Innovations and Research, 3(2), 401-406.

Tsiakaras, G., Petropoulos, S. A., \&Khah, E. M. (2014). Effect of GA3 and nitrogen on yield and marketability of lettuce (Lactuca sativa L.). Australian Journal of crop science, 8(1), 127.

Yan, W., Kang, M. S., Ma, B., Woods, S., \& Cornelius, P. L. (2007). GGE biplot vs. AMMI analysis of genotype-by-environment data. Crop science, 47(2), 643-653. DOI: https://doi. org/10.2135/cropsci2006.06.0374 